\title{
Picomole per Day
}

National Cancer Institute

\section{Source}

National Cancer Institute. Picomole per Day. NCI Thesaurus. Code C122225.

A unit of amount of substance flow rate equivalent to the rate at which one picomole of substance travels to a given object or space over a period of time equal to 24 hours. 